\title{
Changes in Photosynthesis and Oxidative Stress in Wheat Plants Submmited to Herbicides Application ${ }^{1}$
}

\author{
Alterações na Fotossíntese e Estresse Oxidativo em Plantas de Trigo Submetidas a Aplicação de \\ Herbicidas
}

\author{
AGOSTINETTO, D. ${ }^{2}$, PERBONI, L.T. ${ }^{2}$, LANGARO, A.C. ${ }^{2}$, GOMES, J. ${ }^{2}$, FRAGA, D.S. ${ }^{2}$, and \\ FRANCO, J.J. ${ }^{2}$
}

\begin{abstract}
The use of herbicides, even in tolerant crops, can cause stress evidenced by increase phytotoxicity affecting growth and development. The objectives of this study were to evaluate herbicides effect from different mechanisms of action in photosynthetic and oxidative stress parameters, as well visual phytotoxicity and wild radish control in wheat crop, cultivar Quartzo. Two trials were conducted where the first one evaluated the photosynthetic parameters on wheat plants in two seasons collection, following the application of herbicides bentazon, clodinafop, iodosulfuron, metribuzin, metsulfuron and 2,4-D; and the second one evaluated wild radish (Raphanus sativus) control, wheat phytotoxicity and yield due to bentazon, iodosulfuron, metribuzin, metsulfuron and 2,4-D herbicides application. Photosynthetic rate, stomatal conductance and transpiration were negatively affected by metribuzin, metsulfuron and 2,4-D herbicides at 24 and 120 HAS (hours after spraying) compared to control. Oxidative stress was similar or lower to control, when herbicide was applied and, in general, there was no difference between application times. Lipid peroxidation, catalase activity and phenols were higher in the first collection time. The application of herbicides iodosulfuron and 2,4-D reduces chlorophylls and carotenoids in wheat. Herbicides bentazon, iodosulfuron, metribuzin, metsulfuron and 2,4-D are selective to wheat, cultivar Quartzo and do not affect wheat yield. 2,4-D, metribuzin and iodosulfuron are more efficient for wild radish control.
\end{abstract}

Keywords: Triticum aestivum, selectivity, ROS, antioxidant enzymes.

RESUMO - O uso de herbicidas, mesmo em culturas consideradas tolerantes, pode gerar estresses, evidenciados pelo aumento dos sintomas de fitotoxidez, o que prejudica o crescimento $e$ desenvolvimento. O objetivo deste trabalho foi avaliar o efeito de herbicidas de diferentes mecanismos de ação sobre os parâmetros fotossintéticos e do estresse oxidativo, bem como a fitotoxicidade visual e o controle de nabo na cultura do trigo, cultivar Quartzo. Foram realizados dois experimentos: o primeiro avaliou os parâmetros fotossintéticos e do estresse oxidativo em plantas de trigo, em duas épocas de coleta, em função da aplicação dos herbicidas bentazon, clodinafop, iodosulfuron, metribuzin, metsulfuron e 2,4-D; e, o segundo avaliou o controle de nabo (Raphanus sativus), fitotoxicidade e produtividade da cultura do trigo, em função dos herbicidas bentazon, iodosulfuron, metribuzin, metsulfuron e 2,4-D. A taxa fotossintética, condutância estomática e transpiração foram reduzidas pelos herbicidas metribuzin, metsulfuron e 2,4-D, em comparação à testemunha. O estresse oxidativo foi similar ou inferior ao da testemunha quando aplicados herbicidas e, em geral, não houve diferença entre épocas de coletas. A peroxidação lipídica, atividade da catalase e fenóis foram maiores na primeira época de coleta. A aplicação dos herbicidas iodosulfuron e 2,4-D reduz o conteúdo de clorofilas e carotenoides em trigo. Os herbicidas bentazon, iodosulfuron, metribuzin, metsulfuron e 2,4-D são seletivos a cultivar de trigo Quartzo, não modificando a produtividade de grãos, enquanto que 2,4-D, metribuzin e iodosulfuron são mais eficientes no controle de nabo.

Palavras-chaves: Triticum aestivum, seletividade, EROs, enzimas antioxidantes.

Recebido para publicação em 20.5.2015 e aprovado em 23.7.2015.

Universidade Federal de Pelotas, Pelotas, RS, Brasil,<agostinetto.g@gmail.com>.

Planta Daninha, Viçosa-MG, v. 34, n. 1, p. 1-9, 2016 


\section{INTRODUCTION}

Weed management is an important practice in production systems that seek high productivity and quality of agricultural products. The most widely used weed management method is currently the chemical control because of its convenience and efficiency when compared to other methods. Weed control in wheat crops is carried out mainly by the use of herbicides bentazon, clodinafop-propargyl, iodosulfuronmethyl, metsulfuron-methyl, metribuzin and 2,4-dichlorophenoxyacetic acid, which are considered selective to the culture (Reunião..., 2011).

The herbicides selectivity is based on the plant's ability to rapidly metabolize the herbicide, forming non-phytotoxic compounds (Oliveira Jr. 2011, 2007). However, there is a differential selectivity between species, and the genetic makeup of the species or cultivar may determine varying degrees of tolerance or susceptibility to herbicides (Hartwig et al., 2008).

The use of herbicides, even in tolerant cultivars, can generate stress conditions, evidenced by the increase in phytotoxicity, which affects growth, development and productivity. The negative effect of stress is often mediated by the oxidative damage initiated by reactive oxygen species (ROS), such as superoxide radicals $\left(\mathrm{O}_{2}^{-}\right)$, hydroxyl radicals $\left(\mathrm{OH}^{-}\right)$, hydrogen peroxide $\left(\mathrm{H}_{2} \mathrm{O}_{2}\right)$ and singlet oxygen $\left({ }^{1} \mathrm{O}_{2}\right)$ (Gill \& Tuteja, 2010). The ROS react with lipids, proteins, pigments, and nucleic acids, and cause lipid peroxidation, damage to membranes and inactivation of enzymes, i.e., they affect the cells viability (Mittler, 2002). The damage direct response to cell membranes by lipid peroxidation is the cellular contents extravasation to the medium that is wrapped around the damaged tissue (Kruse et al., 2006), disrupting several physiological and metabolic processes of plants.

To prevent oxidative damages caused by the ROS, plant cells have defense mechanisms, including antioxidant enzymes such as superoxide dismutase (SOD), catalase (CAT) and ascorbate peroxidase (APX), as well as non-enzymatic antioxidant compounds such as carotenoids, and polyphenols (Mittler, 2002).

The herbicides selectivity can be visually assessed by means of the phytotoxicity symptoms in plants, and also by the change in photosynthesis and oxidative stress parameters. Also, it is important to check the herbicide efficiency in the target weed control and the effects on productivity, as there are products that reduce crop productivity without visual symptoms and others that cause sharp injuries, but they allow the crop to fully express its productive potential. The objective of this study was to evaluate the effect of herbicides with different mechanisms of action on the photosynthetic and oxidative stress parameters, as well as the visual phytotoxicity and radish control in wheat crop, Quartzo cultivar.

\section{MATERIALS AND METHODS}

Two experiments were conducted, one in a greenhouse (experiment 1) and another one in the field (experiment 2) during the period June-December 2013. For the first experiment, the experimental design was completely randomized with four replications. The experimental units consisted of plastic pots with a volumetric capacity of $4.0 \mathrm{~L}$, filled with soil whose fertility was previously corrected according to the crop technical indications (Reunião..., 2011). 30 wheat seeds were sown per pot, Quartzo cultivar, and, soon after emergence thinning was held, keeping 20 plants per pot.

Treatments were arranged in a $2 \times 7$ factorial arrangement, in which factor A tested collection times: first collection performed 24 hours after spraying (HAS) the herbicides, and the second collection 120 HAS; and factor B compared herbicides: bentazon (1.2 $\left.\mathrm{L} \mathrm{ha}^{-1}\right)$, clodinafop-propargyl $\left(0.25 \mathrm{~L} \mathrm{ha}^{-1}\right)$, iodosulfuron-methyl (100 $\left.\mathrm{g} \mathrm{ha}^{-1}\right)$, metsulfuronmethyl (3.3 $\left.\mathrm{g} \mathrm{ha}^{-1}\right)$, metribuzin (0.3 $\left.\mathrm{L} \mathrm{ha}^{-1}\right)$, 2,4-D (1.5 $\mathrm{L} \mathrm{ha}^{-1}$ ) and control without application. Mineral oil was added to the spray mix of herbicides bentazon $\left(1.0 \mathrm{~L} \mathrm{ha}^{-1}\right)$, clodinafop-propargyl (0.5\%) and metsulfuronmethyl $(0.1 \%)$ and spreader-sticker to the herbicide iodosulfuron-methyl $(0.3 \%)$ spray mix. 
The herbicide treatment application, carried out when the plants were in tillering stage, was done with knapsack sprayer pressurized with with $\mathrm{CO}_{2}$ and equipped with AI110.015 fan-type nozzles, distributing a spray mix volume equivalent to $120 \mathrm{~L} \mathrm{ha}^{-1}$.

The photosynthetic parameters were assessed 120 hours after spraying the herbicides on mature and fully expanded leaves, using an infrared gas analyzer (IRGA, model LI $6400 \mathrm{XT}$ ). The variables analyzed were: photosynthetic rate $\left(\mu \mathrm{mol} \mathrm{m} \mathrm{m}^{-2} \mathrm{~s}^{-1}\right)$, transpiration rate $\left(\mathrm{mol} \mathrm{H}_{2} \mathrm{O} \mathrm{m}^{-2} \mathrm{~s}^{-1}\right)$, stomatal conductance of water vapors $\left(\mathrm{mol} \mathrm{H}_{2} \mathrm{O} \mathrm{m}^{-2} \mathrm{~s}^{-1}\right)$, and water-use efficiency (WUE) $\left(\mathrm{mol} \mathrm{CO}_{2} \mathrm{~mol}^{-1}\right.$ $\mathrm{H}_{2} \mathrm{O}$ ), obtained by the ratio between the amount of $\mathrm{CO}_{2}$ fixed by photosynthesis and the amount of water transpired.

For determination of oxidative stress, collections were done 24 and 120 hours after spraying (HAS) the herbicides, and a compound sample with all the plants of the experimental unit was constituted, which were stored at $80{ }^{\circ} \mathrm{C}$ until the variables measurement time. Cellular damage in tissues were determined by the hydrogen peroxide content $\left(\mathrm{H}_{2} \mathrm{O}_{2}\right)$, according to what was described by Sergier et al. (1997). The superoxide dismutase (SOD) activity was determined according to the methodology adapted by Peixoto (1999), from Del Longo et al. (1993) and Giannopolitis $\&$ Ries (1977). The ascorbate peroxidase (APX) and catalase (CAT) enzymes activity was determined by consumption of $\mathrm{H}_{2} \mathrm{O}_{2}$ (extinction coefficient of $2.9 \mathrm{mM} \mathrm{cm}^{-1}$ and $39.4 \mathrm{mM} \mathrm{cm}^{-1}$, respectively), according to the methodology described by Azevedo et al. (1998). The thiobarbituric acid (TBARS) reactive species were determined via accumulation of malondialdehyde (MDA), according to the method described by Health \& Packer (1968). The determination of total phenolic compounds was done according to Singleton \& Rossi (1965).

The chlorophyll and total carotenoids contents were determined in samples of $0.1 \mathrm{~g}$, macerated in a mortar in the presence of $5 \mathrm{~mL}$ of acetone at $80 \%(\mathrm{v} / \mathrm{v})$. The material was centrifuged at $12,000 \mathrm{rpm}$ for 10 minutes and the supernatant was transferred to a $20 \mathrm{~mL}$ volumetric flask, adding acetone at $80 \%(\mathrm{v} / \mathrm{v})$ to this volume. The contents of chlorophyll $a$, $b$, total $(a+b)$ and total carotenoids were calculated by the Lichtenthaler (1987) formulas, from the solution absorbance obtained by spectrophotometry at 647,663 and $470 \mathrm{~nm}$, expressing the results in $\mathrm{mg} \mathrm{g}^{-1}$ of FM (fresh matter).

In the second experiment, the experimental design was randomized blocks with four replications. Quartzo wheat cultivar was seeded at a density of $126 \mathrm{~kg} \mathrm{ha}^{-1}$, being the basis fertilization performed together with sowing, using $460 \mathrm{~kg} \mathrm{ha}^{-1}$ of the NPK 13-13-13 formulation, according to soil analysis (Reunião..., 2011). For side dressing, 80 kg ha-1 of nitrogen were used as urea, divided between the beginning of tillering and the beginning of stem elongation.

The herbicide treatments, the doses, the stage and the method of application are the same as in the first experiment, except for clodinafop herbicide, which was applied in total area for control of poaceae species. Preventively, there were two applications of fungicide $\mathrm{FOX}^{\circledR}$ (trifloxistrobina + protioconazol $-0.4 \mathrm{~L} \mathrm{ha}^{-1}$ ) plus methylated soybean oil $(0.5 \%)$, at 46 and 68 days after emergence (DAE); and application of Nativo ${ }^{\circledR}$ (trifloxistrobina + tebuconazol - $0.75 \mathrm{~L} \mathrm{ha}^{-1}$ ) plus methylated soybean oil (0.25\%) at 108 DAE.

The variables visually assessed were selectivity to culture at 7 and 21 days after treatments (DAT) and radish control at 14 and 28 DAT. To quantify the selectivity, percentages in a scale from 0 (no phytotoxicity) to 100 (plant death) were assigned. For weed control, compared to unchecked control, percentage ranks ranging from zero, corresponding to no effect, to 100 , which indicates plant death, were assigned. Productivity was calculated from the grain mass obtained in the floor area of the plot $\left(3.57 \mathrm{~m}^{2}\right)$, extrapolated to 1.0 hectare, with humidity corrected to $13 \%$.

The data obtained in experiments 1 and 2 were analyzed for normality and subsequently subjected to analysis of variance ( $\leq \leq 0.05)$. In experiment 1 , in case of significance, the herbicidal effects were examined by Duncan's test $(p \leq 0.05)$, and the effects of collection times by t-test $(p \leq 0.05)$, while for experiment 2 , in case of significance, the 
means were compared by the Duncan's test $(\mathrm{p} \leq 0.05)$.

\section{RESULTS AND DISCUSSION}

Regarding the photosynthetic parameters, there was a reduction of variables photosynthetic rate, stomatal conductance and transpiration when herbicides metribuzin, metsulfuron and 2,4-D were applied to wheat plants, compared to the control, bentazon and clodinafop (Table 1). Reducing these photosynthetic parameters reinforces the hypothesis of stress caused by herbicides applied to wheat crop. For iodosulfuron, there was a difference only when compared to the control in the photosynthetic rate variable. There was no statistical significance for the water-use efficiency - WUE (data not shown).

Table 1 - Photosynthetic rate $\left(\mu \mathrm{mol} \mathrm{m} \mathrm{m}^{-2} \mathrm{~s}^{-1}\right)$, stomatal conductance $\left(\mathrm{mol} \mathrm{m} \mathrm{m}^{-2} \mathrm{~s}^{-1}\right)$ and transpiration $\left(\mathrm{mol} \mathrm{H}_{2} \mathrm{O} \mathrm{m}^{-2} \mathrm{~s}^{-1}\right.$ ) of wheat plants, 120 hours after spraying different herbicides

\begin{tabular}{|l|c|c|c|}
\hline Treatment & Photosynthesis & Conductance & Transpiration \\
\hline Control & $25.713 \mathrm{a}$ & $0.414 \mathrm{ab}$ & $20.425 \mathrm{ab}$ \\
\hline Bentazon & $22.588 \mathrm{a}$ & $0.410 \mathrm{ab}$ & $16.913 \mathrm{bc}$ \\
\hline Clodinafop & $26.235 \mathrm{a}$ & $0.519 \mathrm{a}$ & $22.788 \mathrm{a}$ \\
\hline Iodosulfuron & $16.925 \mathrm{~b}$ & $0.364 \mathrm{abc}$ & $15.883 \mathrm{bc}$ \\
\hline Metsulfuron & $10.967 \mathrm{c}$ & $0.140 \mathrm{~d}$ & $6.957 \mathrm{~d}$ \\
\hline Metribuzin & $16.113 \mathrm{~b}$ & $0.253 \mathrm{bcd}$ & $12.033 \mathrm{~cd}$ \\
\hline 2,4-D & $13.269 \mathrm{bc}$ & $0.205 \mathrm{~cd}$ & $10.000 \mathrm{~d}$ \\
\hline
\end{tabular}

Means followed by same letters in the column do not differ by Duncan's test $(\mathrm{p} \leq 0.05)$.

Photosynthesis and, consequently, respiration, depend on a constant flow of $\mathrm{CO}_{2}$ and $\mathrm{O}_{2}$ in the cell, and this flow is free, depending on the gas concentration in intercellular spaces (Messinger et al., 2006). Stomatal conductance is responsible for water and $\mathrm{CO}_{2}$ inflow and output by the stomata; thus, the lower its opening, the higher the stomatal resistance and consequent decrease in transpiration (Taiz \& Zeiger, 2009). Under stress conditions, the plant tends to close its stomata as a defense mechanism against loss of water, increasing resistance and, consequently, reducing stomatal conductance (Taiz \& Zeiger, 2009).
With regard to herbicides of the sulphonylurea chemical group, there were major changes in photosynthetic parameters in the treatment with metsulfuron, compared to iodosulfuron (Table 1). Herbicides belonging to sulfonylureas have, as a primary effect, the inhibition of the acetolactate synthase (ALS) enzyme, chlorosis and necrosis and thus growth retardation (Oliveira Jr., 2011). In addition, side effects from ALS inhibition, such as synthesis interruption of amino acids valine, leucine and isoleucine, change in photosynthesis and respiration, also contribute to the damage and even death of the plants (Zhou et al., 2007). One study has evaluated the application of iodosulfuron mixed with mesosulfuron-methyl in increasing concentrations, and an increase of MDA content in wheat plants and reduction in stomatal conductance and photosynthetic rate were observed (Guo et al., 2009).

The metribuzin treatment has also reduced the photosynthetic rate of wheat plants, Quartzo cultivar (Table 1). This herbicide belongs to the chemical group of triazines and interferes with the electron transport chain between the primary and secondary acceptors of photosystem II (Oliveira Jr., 2011). With the blockade of photosystem II after using metribuzin, there is an increase in the nonphotochemical extinction coefficient and formation of superoxide radicals $\left(\mathrm{O}_{2}^{-}\right)$quickly acting on the components of the photosynthetic apparatus (Asada, 2006).

The oxidative stress was evaluated from the $\mathrm{H}_{2} \mathrm{O}_{2}$ content, and an interaction between herbicides and collection times was observed (Table 2). $\mathrm{H}_{2} \mathrm{O}_{2}$ content 24 hours after spraying the plants subjected to bentazon and 2,4-D was lower than the control and other herbicide treatments. As for 120 hours after spraying, there was less accumulation in plants where metsulfuron and 2,4-D were applied, compared to the control.

To evaluate the application of herbicides in beans and maize, it was found that the $\mathrm{H}_{2} \mathrm{O}_{2}$ content of bean plants treated with atrazine (same chemical group of metribuzin and bentazone - PSII inhibitor) and maize treated with rimsulfuron (same chemical group of iodosulfuron and metsulfuron - ALS inhibitor) 
Table 2 - Hydrogen peroxide content $\left(\mathrm{H}_{2} \mathrm{O}_{2}\right)\left(\mu \mathrm{M} \mathrm{g}^{-1}\right.$ of FM) and superoxide dismutases (SOD) enzyme activity (UA mg ${ }^{1}$ prot.) in wheat leaves collected at 24 and 120 hours after spraying (HAS) the herbicides

\begin{tabular}{|l|c|c|c|c|}
\hline \multirow{2}{*}{ Treatment } & \multicolumn{2}{|c|}{$\mathrm{H}_{2} \mathrm{O}_{2}$} & \multicolumn{2}{c|}{ SOD } \\
\cline { 2 - 5 } & \multicolumn{3}{|c|}{ Collecting seasons } \\
\cline { 2 - 5 } & $24 \mathrm{HAS}$ & $120 \mathrm{HAS}$ & $24 \mathrm{HAS}$ & $9.24 \mathrm{~b}$ \\
\hline Control & $0.110 \mathrm{a}^{\mathrm{ns}}$ & $0.081 \mathrm{ab}$ & $8.69 \mathrm{a}^{\mathrm{ns}}$ & $9.99 \mathrm{~b}$ \\
\hline Bentazon & $0.074 \mathrm{c}^{\mathrm{ns}}$ & $0.091 \mathrm{a}$ & $7.25 \mathrm{a}^{\mathrm{ns}}$ & $13.83 \mathrm{a}$ \\
\hline Clodinafop & $0.089 \mathrm{ab}^{\mathrm{ns}}$ & $0.069 \mathrm{abc}$ & $8.56 \mathrm{a}^{\mathrm{ns}}$ & $10.37 \mathrm{~b}$ \\
\hline Iodosulfuron & $0.093 \mathrm{ab}^{\mathrm{ns}}$ & $0.087 \mathrm{ab}$ & $10.06 \mathrm{a}^{\mathrm{ns}}$ & $10.49 \mathrm{~b}$ \\
\hline Metsulfuron & $0.107 \mathrm{a}^{*}$ & $0.060 \mathrm{bc}$ & $7.92 \mathrm{a}^{\mathrm{ns}}$ & $6.96 \mathrm{c}$ \\
\hline Metribuzin & $0.082 \mathrm{ab}^{\mathrm{ns}}$ & $0.082 \mathrm{ab}$ & $7.91 \mathrm{a}^{\mathrm{ns}}$ & $9.58 \mathrm{~b}$ \\
\hline 2,4-D & $0.048 \mathrm{c}^{\mathrm{ns}}$ & $0.047 \mathrm{c}$ & $7.87 \mathrm{a}^{\mathrm{ns}}$ & \\
\hline
\end{tabular}

Means followed by same letters in the column do not differ by Duncan's test $(\mathrm{p} \leq 0.05)$. ${ }^{\text {ns }}$ non significant and $*$ significant by the t-test $(\mathrm{p} \leq 0.05)$.

did not differ from the content of the control plants (Hassan \& Nemat Alla, 2005), corroborating the results obtained in this study.

In relation to the collection times, there were differences only for the metsulfuron herbicide, where the $\mathrm{H}_{2} \mathrm{O}_{2}$ content in plants in 120 HAS was lower than the result obtained in 24 HAS (Table 2). Increased production of ROS during stress may pose a threat to the cells but can also act as stress-response pathways activation signal and defense paths. Thus, ROS may be viewed as cellular stress indicators and as secondary messengers involved in the stress response by means of signal transduction (Mittler, 2002).

SOD is an important enzyme of antioxidant defense and occurs in various cellular compartments, catalyzing the dismutation of toxic radicals $\mathrm{O}_{2}$-in $\mathrm{H}_{2} \mathrm{O}_{2}$ and $\mathrm{O}_{2}$ (Gill \& Tuteja, 2010), providing plant protection and tolerance to herbicides. The results have shown an interaction among herbicides and collection times on SOD activity (Table 2), but SOD results have shown no difference between the herbicides in 24 HAS. As for 120 HAS, there was an increased SOD activity in plants exposed to clodinafop herbicide and lower activity when using metribuzin, comparing to the control and the other treatments. Still, it was observed that there was no difference among the collection times.

Possibly, changes in SOD activity are related to the species sensitivity to the herbicide mode of action, namely an increased activation of SOD indicating greater generation of ROS, especially of $\mathrm{O}_{2}^{-}$, which serves as a substrate for SOD (Gar'kova et al., 2011). When applying the herbicide chlorotoluron in wheat plants, an increase in oxidative stress and SOD activity were observed, which may represent a condition of oxidative stress (Song et al., 2007). Treatments with the herbicide clodinafop have induced oxidative stress in wheat, maize and rye plants (Lukatkin et al., 2013).

In the present study, there were no interaction or simple effect of herbicides and collection times on the ascorbate peroxidase (APX) activity (data not shown). For APX, it is hypothesized that there is a variability in the response of different isoforms present in wheat against the use of herbicides. However, the enzyme activity method is based on results from the average of all isoforms; thus, it minimizes the detection of isolated isoforms that exhibit response to stress, generating the need to characterize which ones are involved in the defense mechanism activated by the herbicides.

For catalase (CAT) there was a simple effect to herbicide (Table 3) and collection (Table 4). Data on CAT have shown an increased activity of the enzyme in treatments with 2,4-D herbicide, compared to the control and to clodinafop (Table 3). CAT is considered, together with SODs, the most effective antioxidant enzyme. To evaluate oxidative stress in bean plants treated with atrazine, a 
Table 3 - Catalase (CAT) enzyme activity ( $\mu \mathrm{M} \mathrm{H}_{2} \mathrm{O}_{2} \mathrm{~min}^{-1} \mathrm{mg}^{-1}$ prot.), thiobarbituric acid (TBARS) reactive species (nM MDA g-1 of FM), contents of chlorophyll $a, b$, total $(a+b)$ and total carotenoids $(C a r)\left(\mathrm{mg} \mathrm{g}^{-1}\right)$ extracted from wheat leaves on which different herbicides were applied

\begin{tabular}{|l|l|l|l|l|l|c|}
\hline \multicolumn{1}{|c|}{ Treatment } & CAT & TBARs & $a$ & $b$ & $a+b$ & $C a r$ \\
\hline Control & $0.645 \mathrm{~b}$ & $21.322 \mathrm{a}$ & $1.688 \mathrm{a}$ & $0.519 \mathrm{a}$ & $2.207 \mathrm{a}$ & $0.428 \mathrm{a}$ \\
\hline Bentazon & $0.709 \mathrm{ab}$ & $23.555 \mathrm{a}$ & $1.449 \mathrm{ab}$ & $0.465 \mathrm{ab}$ & $1.915 \mathrm{ab}$ & $0.362 \mathrm{ab}$ \\
\hline Clodinafop & $0.658 \mathrm{~b}$ & $18.399 \mathrm{a}$ & $1.414 \mathrm{abc}$ & $0.434 \mathrm{ab}$ & $1.848 \mathrm{abc}$ & $0.369 \mathrm{ab}$ \\
\hline Iodosulfuron & $0.739 \mathrm{ab}$ & $21.239 \mathrm{a}$ & $1.231 \mathrm{bc}$ & $0.385 \mathrm{bc}$ & $1.616 \mathrm{bc}$ & $0.332 \mathrm{~b}$ \\
\hline Metsulfuron & $0.727 \mathrm{ab}$ & $26.200 \mathrm{a}$ & $1.414 \mathrm{abc}$ & $0.437 \mathrm{ab}$ & $1.851 \mathrm{abc}$ & $0.361 \mathrm{ab}$ \\
\hline Metribuzin & $0.703 \mathrm{ab}$ & $20.036 \mathrm{a}$ & $1.595 \mathrm{a}$ & $0.463 \mathrm{ab}$ & $2.071 \mathrm{a}$ & $0.433 \mathrm{a}$ \\
\hline 2,4-D & $0.793 \mathrm{a}$ & $29.790 \mathrm{a}$ & $1.139 \mathrm{c}$ & $0.349 \mathrm{c}$ & $1.488 \mathrm{c}$ & $0.292 \mathrm{c}$ \\
\hline
\end{tabular}

Means followed by same letters in the column do not differ by Duncan's test $(\mathrm{p} \leq 0.05)$.

Table 4 - Catalase (CAT) enzyme activity $\left(\mathrm{mM} \mathrm{H} \mathrm{O}_{2} \mathrm{~min}^{-1} \mathrm{mg}^{-1}\right.$ prot.), thiobarbituric acid (TBARS) reactive species ( $\mathrm{nM}$ MDA $\left.\mathrm{g}^{-1} \mathrm{FM}\right)$ and total phenols (mg GAE $\mathrm{g}^{-1}$ of FM), extracted from wheat leaves collected at 24 and 120 hours after spraying the herbicides

\begin{tabular}{|c|c|l|l|}
\hline Collection $(\mathrm{h})$ & CAT & TBARS & Phenols \\
\hline 24 & $0.756^{* 1 /}$ & $29.410^{*}$ & $21.587^{*}$ \\
\hline 120 & 0.671 & 16.793 & 13.996 \\
\hline
\end{tabular}

* significant by $\mathrm{t}$-test $(\mathrm{p} \leq 0.05)$.

decrease in SOD and CAT activities and increased content of $\mathrm{H}_{2} \mathrm{O}_{2}$ were observed. This decrease in SOD activity indicates that high $\mathrm{H}_{2} \mathrm{O}_{2}$ levels are not due to active production but to decreased ability of its disposal (Hassan $\&$ Nemat Alla, 2005). The lowest accumulation of $\mathrm{H}_{2} \mathrm{O}_{2}$ in plants subjected to herbicides bentazon and 2,4-D in 24 HAS and metsulfuron and 2,4-D in 120 HAS (Table 2) may be related to higher CAT enzyme activity (Table 3 ).

In relation to the collection times, there was an increased activity of CAT in the first collection season (24 HAS), compared to the second one (120 HAS) (Table 4). In determining the antioxidant activity in wheat and rye with the application of atrazine and fluorodifen, there were no differences in CAT activity, comparing control and herbicide treatments in 24, 48 and 72 HAS (Del Buono et al., 2011).

For the lipid peroxidation, a single acting herbicide (Table 3) and collection times (Table 4) were observed. However, there was no difference between the herbicides (Table 3), and an increased MDA accumulation in absolute values was observed in the treatments with metsulfuron and 2,4-D. In assessing the application of atrazine and fluorodifen in wheat plants, no change in MDA content of 24, 48 and 72 HAS was found, comparatively to the control (Del Buono et al., 2011). MDA is considered a good marker for the structural integrity of membranes, for indicating the level of damage to lipids by oxidation reactions (Ekmekci \& Terzioglu, 2005).

With regard to collection times, it was observed that in the first collection there was greater accumulation of MDA compared to the second one (Table 4). In general, higher MDA content in 24 HAS indicates increased oxidative stress on wheat plants after herbicide application. The reduction of MDA content in 120 HAS indicates less damage to the membranes due to the plants ability to activate mechanisms responsible for the metabolism and elimination of harmful compounds.

Under normal growth conditions, ROS production is limited and efficiently removed by the plant defense system, thus preventing oxidative damage to cellular compounds (Gill $\&$ Tuteja, 2010). Cell damage arises when ROS production exceeds the capacity of antioxidant defense, that is, if the photoprotection and antioxidant mechanisms are overburdened, the ROS can alter cell membranes by means of the accumulation of peroxidative products and peroxidative degradation of unsaturated fatty acids (Gill \& Tuteja, 2010).

In this study, there was no interaction between herbicides and collections for the 
variables: chlorophyll $a$, chlorophyll $b$, total chlorophyll and carotenoids, but a simple herbicidal effect was found (Table 3). Compared to the results obtained, there was a reduction of variables chlorophyll $a, b$, total $(a+b)$ and carotenoids in plants where herbicides iodosulfuron and 2,4-D were applied, compared to the control.

The reduction in chlorophyll content can be a good indicator for monitoring the damage to the plants growth and development (Song et al., 2007). In addition to its effect on photosynthesis, carotenoids exert an antioxidant function in chloroplasts due to the ability to extinguish the ROS that are naturally formed during this process (Kim et al., 2004). The reduction of the carotenoid contents can cause oxidative stress due to the oxidative degradation of chlorophylls and rapid destruction of thylakoid membranes by excessive ROS generated, resulting in tissue discoloration, necrosis, desiccation and death (Kim et al., 2004).

The lower content of pigments in plants on which 2,4-D was applied (Table 3) may result from the greater lipid peroxidation (TBARS) (Table 3), although difference between the herbicides has not been observed. In a study conducted by Wu et al. (2010), exposing rice plants to fluroxypyr (a herbicide from the group of synthetic auxins) has also suppressed the formation of chlorophyll, suggesting that this herbicide can be active in the transport chain of chloroplast electrons, changing the plants photosynthesis.

It is hypothesized that the reduction in the carotenoid content (Table 3) and stomatal closure provided by the herbicide 2,4-D (Table 1) can be explained by the cleavage of xanthophylls (carotenoids) to the abscisic acid (ABA) biosynthesis (Grossman, 2000). According to this author, auxin-mimetic herbicides stimulate ethylene biosynthesis, which, besides causing epinasty of leaves, acts stimulating the abscisic acid (ABA) biosynthesis, which in turn inhibits the plants growth, causing stomatal closure, which limits the assimilation of $\mathrm{CO}_{2}$ and hence the biomass production.

For total phenols, only collection time effect was observed, being higher the content of phenols in the first period, compared to the second one (Table 4). The increase in phenolic compounds increases the plant antioxidant activity due to the reducing properties and chemical structure of these molecules (Sousa et al., 2007).

Regarding the results obtained in the second experiment (in the field), it was found that the herbicide treatments showed low phytotoxicity in wheat plants (Table 5). The bentazon, metribuzin and metsulfuron treatments have caused phytotoxicity only at $7 \mathrm{DAT}$. As for the treatments with iodosulfuron and 2,4-D, they were the ones that showed damage to the crops up to 21 DAT, with subsequent recovery during their development.

Wheat crop is more tolerant to 2,4-D when it is found between the tillering stage and early stem elongation, while very early applications may cause morphological deformation, such as defective ears, curled leaves and reduced stature (Roman et al., 2006).

Table 5 - Herbicides phytotoxicity in wheat at 7 and 21 days after treatment (DAT), turnip control at 14 and 28 DAT and wheat productivity $\left(\mathrm{kg} \mathrm{ha}^{-1}\right)$ by applying different herbicides

\begin{tabular}{|l|c|c|c|c|c|}
\hline \multirow{2}{*}{ Treatment } & \multicolumn{2}{|c|}{ Phytotoxicity (\%) } & \multicolumn{2}{c|}{ Control (\%) } & Productivity \\
\cline { 2 - 6 } & 7 DAT & 21 DAT & 14 DAT & 28 DAT & $\left(\mathrm{kg} \mathrm{ha}^{-1}\right)$ \\
\hline Control & $0 \mathrm{c}$ & $0 \mathrm{~b}$ & $0 \mathrm{~d}$ & $0 \mathrm{~d}$ & $2548 \mathrm{~b}$ \\
\hline Bentazon & $0.5 \mathrm{bc}$ & $0 \mathrm{~b}$ & $66 \mathrm{c}$ & $68 \mathrm{c}$ & $5299 \mathrm{a}$ \\
\hline Iodosulfuron & $3.3 \mathrm{a}$ & $2.0 \mathrm{a}$ & $77 \mathrm{abc}$ & $89 \mathrm{ab}$ & $5697 \mathrm{a}$ \\
\hline Metribuzin & $2.5 \mathrm{ab}$ & $0 \mathrm{~b}$ & $88 \mathrm{a}$ & $93 \mathrm{ab}$ & $5667 \mathrm{a}$ \\
\hline Metsulfuron & $2.0 \mathrm{abc}$ & $0 \mathrm{~b}$ & $75 \mathrm{bc}$ & $84 \mathrm{~b}$ & $5534 \mathrm{a}$ \\
\hline $2,4-\mathrm{D}$ & $0 \mathrm{c}$ & $2.5 \mathrm{a}$ & $86 \mathrm{ab}$ & $97 \mathrm{a}$ & $5475 \mathrm{a}$ \\
\hline
\end{tabular}

Means followed by same letters in the column do not differ by Duncan's test $(p \leq 0.05)$. 
For the variable control, it was observed that iodosulfuron, metribuzin and 2,4-D showed higher values than the other treatments (Table 5). In a study evaluating radish control with different herbicides, the authors have found lower control values when using metsulfuron and bentazon, comparing to the 2,4-D and iodosulfuron treatments (Vargas \& Roman, 2005), which corroborates this research.

With regard to productivity, it was found that the herbicide treatments were not statistically different from each other, but showed higher values compared to the control (Table 5). Competition from weeds in the control treatment has reduced grain yield by approximately $54 \%$, compared to the average of the herbicide treatments. In addition, radish infestations make harvest difficult due to its fibrous stems and siliques, seed contamination and grains storage.

The results indicate that photosynthetic rate, stomatal conductance and transpiration of wheat plants were reduced by herbicides metribuzin, metsulfuron and 2,4-D, compared to the control. Oxidative stress was similar or lower than in the control when herbicides were applied and, in general, there was no difference between harvest dates. SOD activity was similar in herbicides in 24 HAS, while CAT enzyme activity was higher in plants treated with 2,4-D. Lipid peroxidation and catalase activity and phenols were higher in the first season of collection. The application of iodosulfuron herbicides and 2,4-D reduces the content of chlorophyll and carotenoids in wheat. Herbicides bentazon, iodosulfuron, metribuzin, metsulfuron and 2,4-D are selective to Quartz wheat cultivar, not modifying grain yield, while $2,4-\mathrm{D}$, metribuzin and iodosulfuron are more efficient in controlling radish.

\section{LITERATURE CITED}

ASADA, K. Production and scavenging of reactive oxygen species in chloroplasts and their functions. Plant Physiol., v. 141, n. 2, p. 391-396, 2006.

AZEVEDO, R. A. et al. Response of antioxidant enzymes to transfer from elevated carbon dioxide to air and ozone fumigation, in the leaves and roots of wild-type and a catalase-deficient mutant of barley. Physiol. Plant., v. 104, n. 2, p. 280-292, 1998.
DEL BUONO, D. et al. Comparative study on the interference of two herbicides in wheat and Italian ryegrass and on their antioxidant activities and detoxification rates. J. Agric. Food Chem., v. 59, n. 22, p. 12109-12115, 2011.

DEL LONGO, O. T. et al. Antioxidant defenses under hyperoxygenic conditions in leaves of two lines of maize with differential sensitivity to drought. Plant Cell Physiol., v. 34, n. 7, p. 1023-1028, 1993.

EKMEKCI, Y.; TERZIOGLU, S. Effects of oxidative stress induced by paraquat on wild and cultivated wheats. Pestic. Biochem. Physiol., v. 83, n. 2-3, p. 69-81, 2005.

GAR'KOVA, A. N. et al. Treatment with the herbicide granstar induces oxidative stress in cereal leaves. Russian J. Plant Physiol., v. 58, n. 6, p. 1074-1081, 2011.

GIANNOPOLITIS, C. N.; RIES, S. K. Superoxide dismutase. Plant Physiol., v. 59, n. 2, p. 309-314, 1977.

GILL, S. S.; TUTEJA, N. Reactive oxygen species and antioxidant machinery in abiotic stress tolerance in crop plants. Plant Physiol. Biochem., v. 48, n. 12, p. 909-930, 2010.

GROSSMAN, K. Mode of action of auxin herbicides: a new ending to a long, drawn out story. Trends Plant Sci., v. 5, n. 12 , p. $506-508,2000$.

GUO, X. et al. Effects of Sigma broad on photosynthesis and stomatal conductance of winter wheat. Agric. Technol. Serv., v. 26, n. 1, p. 71-72, 2009.

HARTWIG, I. et al. Tolerância de trigo (Triticum aestivum) e aveia (Avena sp.) a herbicidas inibidores da enzima acetolactato sintase (ALS). Planta Daninha, v. 26, v. 2, p. $361-368,2008$.

HASSAN, N. M.; NEMAT ALLA, M. M. Oxidative stress in herbicide treated broad bean and maize plants. Acta Physiol. Plant., v. 27, n. 4, p. 429-438, 2005.

HEALTH, R. L.; PACKER, L. Photoperoxidation in isolated chloroplasts: I. Kinetics and stoichiometry of fatty acid peroxidation. Arch. Biochem. Biophys., v. 125, n. 1, p. $189-198,1968$.

REUNIÃO DA COMISSÃO BRASILEIRA DE PESQUISA DE TRIGO E TRITICALE. Informações técnicas para trigo e triticale - safra 2012. Dourados, MS: Embrapa Agropecuária Oeste, 2011. 204 p.

KIM, J. S. et al. Death mechanisms caused by carotenoid biosynthesis inhibitors in green and in undeveloped plant tissues. Pestic. Biochem. Physiol., v. 78, n. 1, p. 127-139, 2004.

KRUSE, N. D. et al. Estresse oxidativo em girassol (Helianthus annuus) indica sinergismo para a mistura dos herbicidas metribuzin e clomazone. Planta Daninha, v. 24, n. 2, p. 379-390, 2006. 
LICHTENTHALER, H. K. Chlorophyll and carotenoids: pigments of photosynthetic biomembranes. In: COLOWICK, S. P.; KAPLAN, N. O. (Ed.). Methods enzymology. San Diego: Academic Press, 1987. p. 350-382.

LUKATKIN, A. S. et al. Treatment with the herbicide topik induces oxidative stress in cereal leaves. Pestic. Biochem. Physiol., v. 105, n. 1, p. 44-49, 2013.

MESSINGER, S. M.; BUCKLEY, T. N.; MOTT, K. A. Evidence for Involvement of photosynthetic processes in the stomatal response to $\mathrm{CO}_{2}$. Plant Physiol., v. 140, n. 2, p. 771-778, 2006.

MITTLER, R. Oxidative stress, antioxidants and stress tolerance. Trends Plant Sci., v. 7, n. 9, p. 405-410, 2002.

OLIVEIRA JR, R. S. Mecanismo de ação de herbicidas. In: OLIVEIRA JUNIOR, R. S.; CONSTANTIN, J.; INOUE, M. H. (Ed.). Biologia e manejo de plantas daninhas. Curitiba: Omnipax, 2011. p. 141-192.

PEIXOTO, P. H. P. Aluminum effects on lipid peroxidation and on the activities of enzymes of oxidative metabolism in sorghum. R. Bras. Fisiol. Veg., v. 11, n. 3, p. 137-143, 1999.

ROMAN, E. S.; VARGAS, L.; RODRIGUES, O. Manejo e controle de plantas daninhas em trigo. Passo Fundo: Embrapa Trigo, 2006. 12 p. (Documentos Online, 63). Disponível em: <http://www.cnpt.embrapa.br/biblio/do/ pdo63.pdf. $>$. Acesso em: 30 jan. 2014.
SERGIER, I.; ALEXIEVA, V.; KARANOV, E. Effect of spermine, atrazine and combination between them on some endogenous protective systems and stress markers in plant. Crit. Rev. Acad. Bulg. Sci., v. 51, n. 2, p. 121-124, 1997.

SINGLETON, V. L.; ROSSI, J. A. Colorimetry of total phenolics with phosphomolybdic-phosphotungstic acid reagents. Am. J. Enol. Vitic., v. 16, n. 3, p. 144-158, 1965.

SONG, N. H. et al. Biological responses of wheat (Triticum aestivum) plants to the herbicide chlorotoluron in soils. Chemosphere, v. 68, n. 9, p. 1779-1787, 2007.

SOUSA, C. M. M. et al. Fenóis totais e atividade antioxidante de cinco plantas medicinais. Quím. Nova, v. 30, n. 2, p. 351-355, 2007.

TAIZ, L.; ZEIGER, E. Fisiologia vegetal. 4. ed. Porto Alegre: Artmed, 2009. 819 p.

VARGAS, L.; ROMAN, E. S. Seletividade e eficiência de herbicidas em cereais de inverno. R. Bras. Herbic., v. 3, n. 1, p. 1-10, 2005.

WU, G. L. et al. Fluroxypyr triggers oxidative damage by producing superoxide and hydrogen peroxide in rice (Oryza sativa). Ecotoxicology, v. 19, n. 2, p. 124-132, 2010.

ZHOU, Q. Z. et al. Action mechanisms of acetolactate synthase-inhibiting herbicides. Pestic. Biochem. Physiol., v. 89 , n. 1, p. 89-96, 2007. 